\title{
EFFECT OF GYPSUM AND SULPHUR APPLICATION IN AMELIORATION OF SALINE SOIL AND ENHANCING RICE PRODUCTIVITY \\ Helmy, A. M. ${ }^{1}$; KH. A. Shaban ${ }^{2}$ and M. A. EL-Galad ${ }^{2}$ \\ ${ }^{1}$ Soil Science Dept., Fac. Agric., Zagazig Univ., Zagazig, Egypt \\ ${ }^{2}$ Soil, Water and Enviro. Res. Institute, ARC, Giza, Egypt
}

\begin{abstract}
Studying the effect of applying gypsum and sulphur to counteract the soil salinity hazardous on vegetative growth, yield and quality of rice plants (Oriza sativa L.,cv. Sakha 101) grown on a Saline-Sodic soil at (Sahl El-Tina, Village 4, Gilbana, North Sinai governorate) irrigated with low water quality of El-Salam canal was the main objective of the current study. To fulfill this objective two field experiments were carried out during the two successive seasons of 2011 and 2012. Gypsum was applied at a rate of $10.7 \mathrm{Mg} \mathrm{ha}^{-1}$ while sulphur was added as either elemental sulphur at a rate of $4.8 \mathrm{Mg} \mathrm{ha}^{-1}$ or sulphuric acid at a rate of $1190 \mathrm{~L} \mathrm{ha}^{-1}$. The obtained results could be summarized as follows: The highest values of rice yield and its attributes as well as nutrient contents and uptake values were obtained due to treating the investigated soil with sulphuric acid. Also, the effect of treatments showed a descending increase in the order of, sulphuric acid > sulphur > gypsum > control. The treatment of sulphuric acid was superior to the other treatments. Highest proline $\left(21.3 \mu_{\mathrm{mol} \mathrm{g}} \mathrm{g}^{-1}\right)$ value was recorded due to the treatment of gypsum. Keywords: Saline soil, gypsum, elemental sulphur, sulphuric acid, rice.
\end{abstract}

\section{INTRODUCTION}

Various amendments like gypsum, sulphur, acids, press mud and farmyard manure (FYM) may be used for reclamation of these soils (Sabir et al. 2007; Shaban et al. 2009; Mazhar et al. 2011 and Bello, 2012). The use of gypsum as a source of $\mathrm{Ca}^{2+}$ is a well-established practice for the amelioration and management of sodium saturated water/soils (Amezketa et al. 2005). Being easily available and cheap source of calcium gypsum is commonly used in Egypt. Because of low solubility of gypsum and calcareous nature of soils its efficiency is reduced. However, its effect in the amelioration process continues for few months until the whole quantity of gypsum reacts with the exchangeable sodium (Na) of the soil (Hamza and Anderson 2003). One of the approaches for the economic utilization of moderately salt affected land is to grow salt tolerant crop varieties along with the suitable management of cultural practices. Being moderately salt tolerant, rice is being recommended for cultivation during the amelioration of salt affected soil (Hassan et al., 2001).

Shulphur is a yellow powder ranging in purity from 50 percent to more than 99 percent. When applied for sodic soil reclamation, sulphur has to 
undergo oxidation to form sulphuric acid which in turn reacts with lime present in the soil to form soluble calcium in the form of calcium sulphate: $2 \mathrm{~S}+3 \mathrm{O}_{2}===\rightarrow 2 \mathrm{SO}_{3}$ (microbiological oxidation by Thiobacillus thiooxidans) $\mathrm{SO}_{3}+\mathrm{H}_{2} \mathrm{O}=\rightarrow \mathrm{H}_{2} \mathrm{SO}_{4}$ $\mathrm{H}_{2} \mathrm{SO}_{4}+\mathrm{CaCO}_{3}===\rightarrow \mathrm{CaSO}_{4}+\mathrm{H}_{2} \mathrm{O}+\mathrm{CO}_{2}$ $\mathrm{Na}$ clay micelle $+\mathrm{CaSO}_{4} \Longleftrightarrow \mathrm{Ca}$ clay micelle $+\mathrm{Na}_{2} \mathrm{SO}_{4}$ (leachable)

Abrol et al. (1988). Sulphur also improves the use efficiency of essential plant nutrients, particularly nitrogen and phosphorus (Mazhar et al., 2011). It is one of major nutrients essential for plant growth, root nodule formation of legumes and plant protection mechanisms. Sulphur is one of the essential nutrients for plant growth and it accumulates by about 0.2 to $0.5 \%$ in plant tissue on dry matter basis. It is required in similar amount as that of phosphorus (De Kok et al., 2002 and Ali et al., 2008). It is a building block of protein and a key ingredient in the formation of chlorophyll (Duke and Reisenaue, 1986). Sulphur deficiency has become widespread in many countries, because atmospheric inputs of sulphur will continue to decrease, the deficit in the sulphur input is likely to increase, unless sulphur fertilizers are used. Without adequate $S$, crops cannot reach their full potential in terms of yield or protein content (Zhao et al., 1999). It is required for the synthesis of $S$ containing amino acids such as cystine, cysteine and methionine. Their deficiency results in reduced plant height and stunted growth, reduced tiller, height, spikelet and delayed maturity. Sulphur deficient plants have also less resistance under stress conditions (Doberman and Fairhurst, 2000). Sulphur application enhances the uptake of $\mathrm{N}, \mathrm{P}, \mathrm{K}$ and $\mathrm{Zn}$ by plants, which in turn increases crop productivity. Application of $S$ is a feasible technique to suppress the uptake of undesired toxic elements ( $\mathrm{Na}$ and $\mathrm{Cl}$ ), thus its application is useful not only for increasing crop production and quality of the product but also for improving soil conditions for healthy crop growth (Tandon, 1991). Sulphur improves $\mathrm{K} / \mathrm{Na}$ selectivity and increases the capability of calcium ion to decrease the injurious effects of sodium ions in plants (Wilson et al., 2000, Leigh, 2001 and Badr et al., 2002).

Sulphuric acid may be used in place of gypsum in saline sodic soils. Sulphuric acid reacts with lime to form gypsum $\left(\mathrm{CaSO}_{4} \cdot 2 \mathrm{H}_{2} \mathrm{O}\right)$. The gypsum formed in this reaction has same effect as applied from outside. Following chemical reaction takes place.

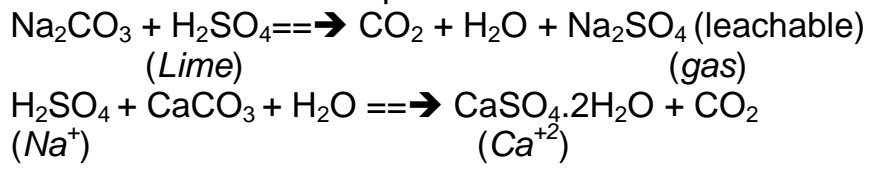

Soil Colloid $+\mathrm{CaSO}_{4}==\rightarrow$ Soil Colloid $+\mathrm{Na}_{2} \mathrm{SO}_{4}$ (Leach down out of root zone).

The presence of lime is important in sodic and saline sodic soils, because during the initial steps of reclamation it can provide $\mathrm{Ca}^{+2}$ if it is treated with acid. When vegetation is established, the release of carbon dioxide converts some calcium carbonate into relatively soluble calcium bicarbonate [ $\left.\mathrm{Ca}\left(\mathrm{HCO}_{3}\right)_{2}\right]$. This naturally released calcium is generally available for reclaiming sodic and saline sodic soils. If 20 liter per acre sulphuric acid or hydrochloric acid is applied as fertigation it could be saved 
the plants from harmful effects of salts. The acid can be applied at the time of soil preparation before sowing. This acid provides native calcium present in the soil available. In others words the acid makes gypsum available. By lowering the $\mathrm{pH}$ of soil, micronutrients become available to crop. It improves soil environment by reducing impact of salinity and high $\mathrm{pH}$ also, reduce soil compactness and enhance soil porosity by replacing sodium of soil with calcium, (Ali and Aslam 2005).

The current investigation aimed at assessing the effect of gypsum, elemental sulphur and sulphuric acid application on the productivity and nutrient contents of rice plants grown on a saline-sodic soil irrigated with moderate saline irrigation water of El-Salam canal.

\section{MATERIALS AND METHODS}

A field experiment was conducted on a saline-sodic soil located in village 4 at Sahl El-Tina plain in the East of Suez Canal, North Sinai Governorate for the two successive summer seasons 2010 \& 2011, cultivated with rice (Oriza sativa cv. Sakha 101). This area is one of the newly reclaimed soils and it is irrigated with ElSalam canal water which is a mixture of agricultural drainage water and fresh water (Nile water) at a ratio of 1:1. A representative soil sample $(0-30 \mathrm{~cm})$ was taken before planting to determine the physical and chemical properties of the investigated soil as well as its content of the nutritional elements (Table 1). Irrigation water $\mathrm{EC}$ and $\mathrm{pH}$ values as well as its contents of some macro and micronutrients were determined during the two successive seasons of the experiment and results are recorded in Table 2.

Table 1. Some physical and chemical properties of the soil used in the

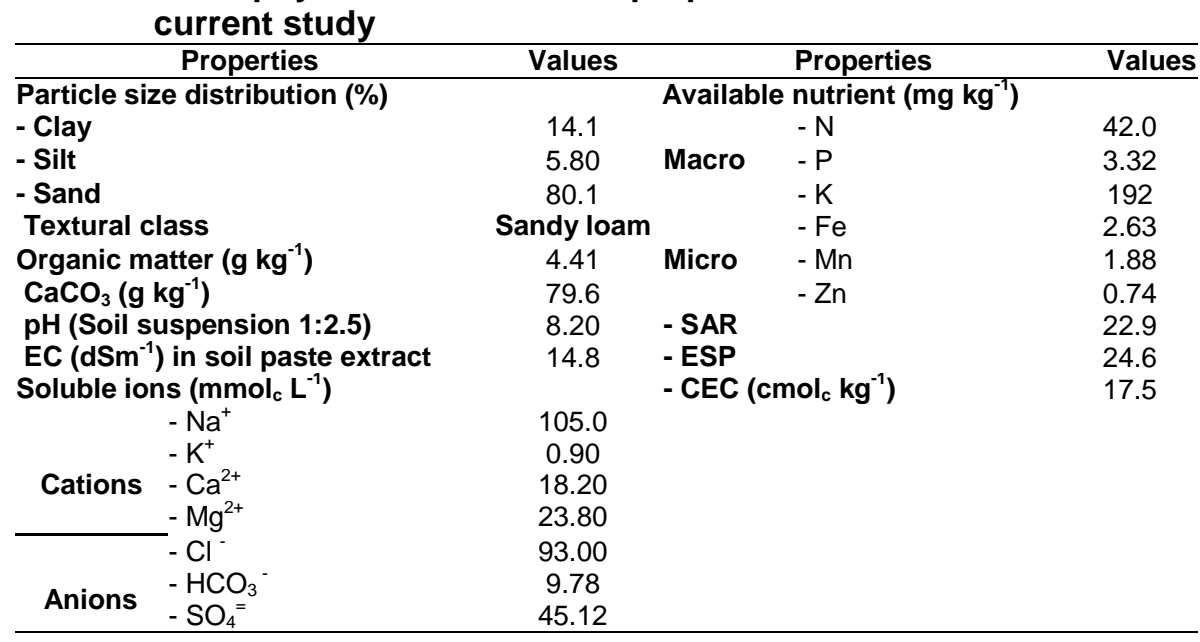


Helmy, A. M. et al.

Table 2. Some chemical properties of irrigation water during irrigating rice plant.

\begin{tabular}{|c|c|c|c|}
\hline \multirow{2}{*}{ Property } & \multicolumn{3}{|c|}{ Season } \\
\hline & 2011 & 2012 & Combined \\
\hline$\overline{\mathrm{pH}}$ & 7.94 & 7.91 & 7.93 \\
\hline $\begin{array}{l}\mathrm{EC}\left(\mathrm{dSm}^{-1}\right) \\
\text { Macronutrients }\left(\mathrm{mg} \mathrm{kg}^{-1}\right)\end{array}$ & 1.34 & 1.38 & 1.36 \\
\hline $\mathrm{N}-\mathrm{NH}_{4}^{+}$ & 15.7 & 13.8 & 14.8 \\
\hline $\mathrm{N}-\mathrm{NO}_{3}^{-}$ & 7.32 & 7.68 & 7.50 \\
\hline $\mathbf{P}$ & 1.91 & 1.84 & 1.88 \\
\hline $\mathrm{K}$ & 8.91 & 8.81 & 8.96 \\
\hline Micronutrients $\left(\mathrm{mg} \mathrm{kg}^{-1}\right)$ & & & \\
\hline $\mathrm{Fe}$ & 0.84 & 0.87 & 0.86 \\
\hline Mn & 1.29 & 1.33 & 1.31 \\
\hline $\mathrm{Zn}$ & 0.68 & 0.73 & 0.71 \\
\hline
\end{tabular}

The experimental design was randomized complete blocks with three replicates. The plot area was $12 \mathrm{~m} \times 13 \mathrm{~m}$. The treatments were 1) control, 2) gypsum, 3) elemental sulphur, 4) sulphuric acid. The experimental soil units were subjected to some pretreatments as follows: 1) leveling the soil surface by using laser technique. 2) deep sub-soiling plough. 3) establishment of field drains at a distance of $10 \mathrm{~m}$ apart and at depth of $90 \mathrm{~cm}$ at drain beginning, and the drainage water flow towards main collectors of $2 \mathrm{~m}$ in depth, and 4 ) establishment of an irrigation canal in the middle part of the experimental unit. Each plot was sown with rice (Oriza sativa cv. Sakha 101) on the 20th and 25th of April, and harvested on the 2nd and 5th of September 2011 and 2012, respectively. Urea (460 $\mathrm{g} \mathrm{N} \mathrm{kg}^{-1}$ ) was applied as soil application at a rate of $285 \mathrm{~kg} \mathrm{~N} \mathrm{ha}^{-1}$ in two equal splits, the first dose was added before the $1^{\text {st }}$ irrigation and the second one was applied before the $2^{\text {nd }}$ irrigation. Phosphorus fertilizer was added to all plots before ploughting and sowing at a rate of $36 \mathrm{~kg} \mathrm{P} \mathrm{ha}^{-1}$ as single superphosphate $\left(68.0 \mathrm{~g} \mathrm{P} \mathrm{kg}^{-1}\right)$. Potassium sulphate $\left(400 \mathrm{~g} \mathrm{~K} \mathrm{~kg}^{-1}\right)$ was applied as soil application at a rate of $89 \mathrm{~kg} \mathrm{~K}$ ha $^{-1}$ in two equal splits, 30 and 45 days after sowing.

The soil amendments used in this study were, gypsum (G), elemental sulphur (ES) and sulphuric acid (SA). Gypsum requirements (GR) were calculated to reduce the initial ESP percentage from 24.6 to $10 \%$ for $30-\mathrm{cm}$ soil matrix depth according to USDA (1954). The gypsum was of $97 \%$ purity and its addition rate was 10.7 mega gram $(\mathrm{Mg})$ ha $^{-1}$. Elemental sulphur and sulphuric acid were added at rates of $4.8 \mathrm{Mg} \mathrm{ha}^{-1}$ and $1190 \mathrm{~L} \mathrm{ha}^{-1}$, respectively. All treatments were applied in two equal splits, 30 and 60 days before planting and interrupted by leaching process then followed by flipping and deep plowing of the sub-soil.

Plant samples were taken at 30,60, 90 and 130 days after sowing (DAS) corresponding to seedling, tillering, heading and maturity stages, respectively. Total $\mathrm{N}, \mathrm{P}$ and $\mathrm{K}$ as well as $\mathrm{Fe}, \mathrm{Mn}$ and $\mathrm{Zn}$ contents in plant samples were determined.

At maturity, plants grown on $2 \mathrm{~m}^{2}$ of each plot were harvested, air dried, and yields was recorded. In addition, representative ten plants were taken randomly from each plot and measured for the following characters: plant height $(\mathrm{cm})$, number of spike plant ${ }^{-1}, 1000$-grain weight $(\mathrm{g})$, grains yield $\left(\mathrm{Mg} \mathrm{ha}^{-1}\right)$, straw yield $\left(\mathrm{Mg} \mathrm{ha}^{-1}\right)$. Grain protein content was obtained by multiplying grain $\mathrm{N}$ concentration 
by 5.95 according to the method given in AACC (2000). Protein yield $\left(\mathrm{kg} \mathrm{ha}^{-1}\right)=$ protein percentage $\mathrm{x}$ grain yield $\left(\mathrm{Mg} \mathrm{ha}^{-1}\right) \times 10$.

\section{Methods of analysis}

The plant materials were oven dried at $70^{\circ}$, ground and kept for chemical analyses. $0.4 \mathrm{~g}$ portion was wet-digested using a mixture of concentrated sulphuric and perchloric acids according to Peterbugski (1968). The analyses of plants, soil and water were carried out using the methods described by Black (1965) and Chapman and Pratt (1961). Available and total phosphorus as well as Fe, Mn, and Zn, were extracted using AB-DTPA according to (Soltanpour, 1985) and were determined using Inductively Coupled Plasma (ICP) Spectrometry model 400 . Ammonium and nitrate contents of the irrigation water were determined according to the method described by Markus et al. (1982).

Total chlorophyll was determined according to Saric et al. (1967). Total proline content was determined according to Bates et al. (1973).

\section{Calculations and statistical analysis}

\section{Gypsum requirements (GR)}

Gypsum requirements (GR) were calculated to reduce the initial ESP from 24.6 to $10 \%$ for 30-cm soil matrix as follow: $\mathrm{GR}=\mathrm{ESP}_{\mathrm{i}}-\mathrm{ESP}_{\mathrm{f}} \times \mathrm{CEC} \times 1.72$

\section{0}

Where GR: gypsum requirements $\left(\mathrm{Mg} \mathrm{ha}^{-1}\right), \mathrm{ESP}_{\mathrm{i}}$ : actual initial ESP of the soil, $\mathrm{ESP}_{\mathrm{f}}$ : is the ESP required to be reached by reclamation and CEC: cation exchange capacity $\left(\mathrm{cmol}_{\mathrm{c}} \mathrm{kg}^{-1}\right)$.

\section{Sodium adsorption ratio (SAR)}

Sodium adsorption ratio (SAR) was estimated by using the following equation were

$$
\mathrm{SAR}=\frac{\mathrm{Na}^{+}}{\sqrt{\frac{C a^{2+}+M g^{2+}}{2}}}
$$

where ionic concentrations of the saturation extracts are expressed in $\mathrm{mmol}_{\mathrm{C}} \mathrm{L}^{-1}$

Exchangeable sodium percentage (ESP):

Exchangeable sodium percentage (ESP) was estimated by using the following equation according to USDA (1954).

$$
\mathrm{ESP}=\frac{100(-0.0126+0.01475 \mathrm{SAR})}{1+(-0.0126+0.01475 \mathrm{SAR})}
$$

Treatments were assigned using randomized complete block design with three replications using MSTAT-C developed by Russel (1994). 
Helmy, A. M. et al.

\section{RESULTS AND DISCUSSION}

\section{Effect of sulphur sources and gypsum applications on plant growth and nutrient contents: \\ Macronutrient and micronutrients content at different growth stages:}

Data presented in Fig. 1 illustrated that the application of gypsum and sulphur as elemental sulphur or sulphuric acid increased the concentrations of $\mathrm{N}, \mathrm{P}$ and $\mathrm{K}$ in rice plants compared to the control. This was true at all growth stages. Data also revealed an ascending increases in the order, of sulphuric acid > elemental sulphur > gypsum in all cases. This finding agrees with that of Mazhar et al. (2011) who reported that sulphur increases the uptake of the essential plant nutrients; particularly nitrogen and phosphorus. This means that sulphur application enhanced the uptake of N, P, K and $\mathrm{Zn}$ by the plant due to its synergistic effect on these elements. Application of $S$ is useful not only for increasing crop production and quality of the produce but also improves soil conditions for healthy crop (Zhao, 1999). These results are in agreement with those obtained by Wilson et al. (2000), Leigh (2001) and Badr et al. (2002).

\section{Total chlorophyll and proline content}

It is clear from Fig. 2 that the contents of chlorophyll $(a+b)$ and proline increased owing to the addition of sulphuric acid, elemental sulphur and gypsum, however, the differences among the treatments were insignificant. The highest chlorophyll content $2.51 \mathrm{mg} \mathrm{g}^{-1}$ fresh weight of leaves was obtained due to the application of sulphuric acid which caused $56.9 \%$ increase over the control treatment.

As for proline content data indicate that there are significant differences among the treatments. The increases occurred in proline content followed the descending order: gypsum > elemental sulphur > sulphuric acid > control. Highest proline content $\left(21.3 \mu \mathrm{mol} \mathrm{g}{ }^{-1}\right)$ was observed due to gypsum treatment. Gypsum is a source of soluble $\mathrm{Ca}^{2+}$. Pratiksha et al. (2010) reported that proline content increased as the external supply of calcium to saline soil increased.

\section{Growth characters}

Some growth characters of rice plants are shown in Table 3. Gypsum, elemental sulphur and sulphuric acid treatments significantly increased 1000-grain weight, plant height and number of spikes plant ${ }^{-1}$. These increases may be due to the applied sulphur source provided favorable conditions for some nutritive elements e.g. calcium, is an essential part of plant cell wall structure, provides normal transport and retention of other elements as well as strength in the plant. Among the treatments, sulphuric acid was found to be of the best effect on the above mentioned growth parameters. It was followed by elemental sulphur and then gypsum. The superiority of sulphuric acid might be attributed to its effect on reducing soil $\mathrm{pH}$, improving soil structure and increasing the availability of certain plant nutrients (Niazi, et al., 2001). Data also revealed that application of sulphuric acid increased the plant height, number of spike plant ${ }^{-1}$ and 1000 grains weight by about (29.9, 133 and $72.4 \%)$ compared with untreated plants. Mazhar et al. (2011) reported that application of sulphur and gypsum significantly increased all growth parameters i.e., plant height, stem diameters, fresh weight, and dry weight. These results are in harmony with those obtained by Tan et al. (2000) and Sabir et al. (2007). 
J. Soil Sci. and Agric. Eng., Mansoura Univ., Vol. 4 (10), October, 2013

Fig 1. Macro and micro nutrient concentrations of rice at different growth stages as affected by gypsum, elemental sulphur and sulphuric acid treatments, (combined data)

(G, ES and SA are gypsum, elemental sulphur and sulphuric acid, respectively)

1043 
Helmy, A. M. et al.

(a)

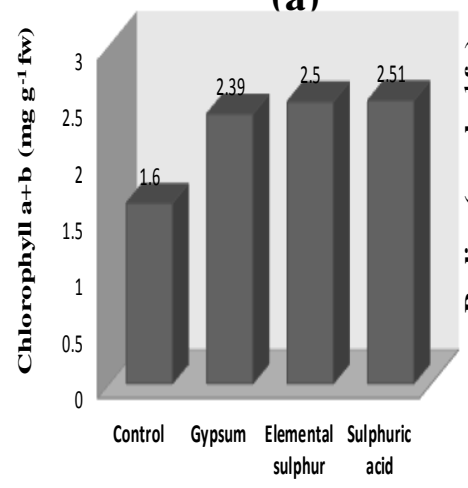

(b)

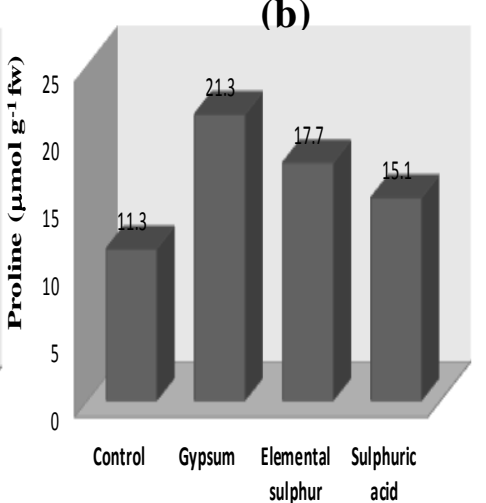

Fig 2. (a), Cholorophyll $a+b$ ( $\mathrm{mg} \mathrm{g}^{-1}$ fresh weight of leaves) and (b), proline ( $\mu \mathrm{mol} \mathrm{g}^{-1}$ fresh weight of leaves) as affected by gypsum, elemental sulphur and sulphuric acid applications (combined data)

Table 3 Yield and yield attributes of rice plants as affected by gypsum, elemental sulphur and sulphuric acid applications during the two growing seasons (2011 and 2012) and their combined effect

\begin{tabular}{|c|c|c|c|c|c|c|c|c|c|}
\hline \multirow[b]{2}{*}{ Treatment } & \multirow[b]{2}{*}{ Season } & \multirow[b]{2}{*}{$\begin{array}{c}\text { Plant } \\
\text { height } \\
(\mathbf{c m})\end{array}$} & \multirow[b]{2}{*}{$\begin{array}{l}\text { No. of } \\
\text { spike } \\
\text { plant }^{-1}\end{array}$} & \multirow[b]{2}{*}{$\begin{array}{c}1000 \\
\text { grain } \\
\text { weight } \\
\text { (g) }\end{array}$} & \multicolumn{3}{|c|}{ Yield $\left(\mathrm{Mg} \mathrm{ha}^{-1}\right)$} & \multirow[b]{2}{*}{ 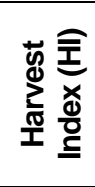 } & \multirow[b]{2}{*}{ 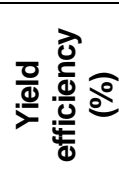 } \\
\hline & & & & & $\begin{array}{l}\overline{8} \\
\frac{0}{\circ} \\
\frac{0}{0}\end{array}$ & $\frac{0}{\frac{C}{\pi}}$ & 喜 & & \\
\hline \multirow{4}{*}{ Control } & 2011 & 67.9 & 2.21 & 25.5 & 14.3 & 5.12 & 9.19 & 0.56 & 39.0 \\
\hline & 2012 & 70.0 & 2.58 & 23.1 & 14.1 & 5.62 & 8.48 & 0.66 & 39.9 \\
\hline & Combined & $68.9 c^{\star}$ & $2.51 \mathrm{~b}$ & $24.3 \mathrm{c}$ & $14.2 \mathrm{~b}$ & $5.38 \mathrm{~b}$ & $8.83 \mathrm{~b}$ & $0.61 \mathrm{~b}$ & $39.4 \mathrm{~b}$ \\
\hline & 2011 & 79.9 & 3.82 & 35.9 & 19.3 & 8.95 & 10.3 & 0.87 & 46.4 \\
\hline \multirow{2}{*}{ Gypsum } & 2012 & 82.6 & 4.52 & 37.5 & 19.8 & 9.24 & 10.5 & 0.88 & 46.8 \\
\hline & Combined & $81.2 \mathrm{~b}$ & $4.17 \mathrm{ab}$ & $36.7 \mathrm{~b}$ & $19.5 \mathrm{a}$ & $9.10 \mathrm{a}$ & $10.4 \mathrm{ab}$ & $0.87 a$ & 46.6 a \\
\hline \multirow{3}{*}{$\begin{array}{l}\text { Elemental } \\
\text { Sulphur }\end{array}$} & 2011 & 85.7 & 5.71 & 36.4 & 19.8 & 9.17 & 10.6 & 0.86 & 46.3 \\
\hline & 2012 & 87.3 & 5.89 & 38.9 & 20.1 & 9.38 & 10.8 & 0.87 & 46.6 \\
\hline & Combined & $86.5 \mathrm{ab}$ & $5.80 a$ & $37.7 \mathrm{~b}$ & $20.0 \mathrm{a}$ & $9.29 a$ & $10.7 \mathrm{a}$ & $0.87 a$ & $46.5 a$ \\
\hline \multirow{2}{*}{$\begin{array}{l}\text { Sulphuric } \\
\text { acid }\end{array}$} & 2011 & 89.0 & 5.77 & 41.2 & 20.4 & 9.33 & 11.1 & 0.84 & 45.7 \\
\hline & $\begin{array}{l}2012 \\
\text { Combined }\end{array}$ & $\begin{array}{c}90.0 \\
89.5 a\end{array}$ & $\begin{array}{c}5.93 \\
5.85 a\end{array}$ & $\begin{array}{c}42.5 \\
41.9 a\end{array}$ & $\begin{array}{c}20.8 \\
20.6 a\end{array}$ & $\begin{array}{c}9.45 \\
9.41 \mathrm{a}\end{array}$ & $\begin{array}{c}11.3 \\
11.2 a\end{array}$ & $\begin{array}{c}0.84 \\
\mathbf{0 . 8 4} \mathbf{a}\end{array}$ & $\begin{array}{c}45.5 \\
45.7 a\end{array}$ \\
\hline \multicolumn{2}{|c|}{ LSD $_{0.05}$ (Combined) } & 5.500 & 2.627 & 1.137 & 1.242 & 0.609 & 0.723 & 0.116 & 4.197 \\
\hline
\end{tabular}




\section{Biological yield}

Data presented in Table 3 show that grains and straw yields were significantly increased due to the addition of gypsum, elemental sulphur and sulphuric acid. The favorable effect of gypsum might be attributed as mentioned before to its content of calcium, which is essential for many plant functions, among which proper cell division and elongation, enzyme activity and metabolism. On the other hand, the favourable effect of sulphur and sulphuric acid might be due to their influence on reducing soil $\mathrm{pH}$, improving soil structure and increasing the availability of certain nutrients. These results are agree with the findings of Sabir et al. (2007) and Farook and Khan, (2010).The maximum straw and grain yields (11.2 and $9.41 \mathrm{Mg}$ $\mathrm{ha}^{-1}$, respectively) were achieved due to application of the sulphuric acid. In this concern, elemental sulphur come next and then gypsum, which was added to fulfill $100 \%$ of the soil gypsum requirement. The increases over the control treatments due to sulphuric acid, elemental sulphur and gypsum were 74.8, 72.6 and $69.0 \%$, respectively for grain yield corresponding to $27.0,21.3$ and $18.1 \%$, respectively for straw yield. These results stand in well agreement with those of Ghaudhry (2001), who concluded that gypsum application to rice and wheat crops at $75 \%$ gypsum requirement enhanced the paddy and grain yield by 18 and $17 \%$, respectively. In this regard, Farook and Khan, (2010) pointed out that the application of a sulphur source increased the grain yield of rice plant by $108 \%$ over the control for Sirajgonj soil and $135 \%$ for Gazipur soil irrespective of application rates. In case of gypsum, the corresponding increments were $35 \%$ and $58 \%$ for Sirajgonj soil and Gazipur soil respectively. Tan et al. (2000) founded that all sulphur sources (ammonium sulphate, sulphur and gypsum) had a positive effect on rice yield from 9 to 10 percent higher than plots receiving no S. Jena et al. (2006), Mazhar et al. (2011) and Jena and Kabi, (2012) went almost to similar findings.

Harvest index $(\mathrm{HI})$ and yield efficiency

Yield efficiency of plants treated with gypsum was the highest. The values were $46.6 \%, 46.5 \%$ and $45.7 \%$ due to gypsum, elemental sulphur, and sulphuric acid, respectively. Data also reveal that there were no significant differences among the treatments. Harvest index showed a similar trend to that for yield efficiency. Farook and Khan, (2010) pointed out that the application of sulfidic material exerted significant effects on increasing the harvest index of rice, but the application of gypsum was found to have positive effects which were not always significant for these plant characters.

\section{Grain protein content}

It can be seen from results presented in Table 4 that the protein content of rice grains significantly increased owing to application of sulphuric acid, elemental sulphur and gypsum. The differences among the treatments were significant while there was no significant difference between elemental sulphur and gypsum treatments. This promoting effect could be related to the higher effect of sulphuric acid on enhancing the growth of rice than gypsum performance. The maximum value of protein $(8.57 \%)$ was obtained due to the application of sulphuric acid which recorded $45.5 \%$ increase over the control treatment. The highest value $\left(802 \mathrm{~kg} \mathrm{ha}^{-1}\right)$ of protein yield was also obtained due to addition of sulphuric acid which gave the highest values of both the nitrogen content and grain yield. 
Helmy, A. M. et al.

Table 4 Protein content (\%) and protein yield $\left(\mathrm{kg} \mathrm{ha}^{-1}\right)$ of rice grains as affected by gypsum, elemental sulphur and sulphuric acid applications during the two growing seasons (2011 and 2012) and their combined effect

\begin{tabular}{|c|c|c|c|}
\hline Treatment & Season & Protein content & $\begin{array}{l}\text { Protein yield } \\
\mathrm{kg} \mathrm{ha}^{-1}\end{array}$ \\
\hline & 2011 & 6.49 & 333 \\
\hline \multirow[t]{3}{*}{ Control } & 2012 & 5.30 & 298 \\
\hline & Combined & $5.89 \mathrm{c}$ & $314 \mathrm{~b}$ \\
\hline & 2011 & 7.44 & 667 \\
\hline \multirow[t]{2}{*}{ Gypsum } & 2012 & 7.74 & 714 \\
\hline & $\begin{array}{c}\text { Combined } \\
2011\end{array}$ & $\begin{array}{c}7.62 \text { b } \\
7.62\end{array}$ & $\begin{array}{c}690 a \\
298\end{array}$ \\
\hline \multirow[t]{2}{*}{ Elemental Sulphur } & 2012 & 8.03 & 752 \\
\hline & $\begin{array}{c}\text { Combined } \\
2011\end{array}$ & $\begin{array}{c}7.85 \mathrm{~b} \\
8.21\end{array}$ & $\begin{array}{c}726 a \\
767\end{array}$ \\
\hline \multirow{2}{*}{ Sulphuric acid } & 2012 & 8.87 & 838 \\
\hline & Combined & $\begin{array}{l}8.57 \mathrm{a} \\
0.364\end{array}$ & $\begin{array}{c}802 \mathrm{a} \\
55.04\end{array}$ \\
\hline
\end{tabular}

See footnotes of Table 3

These results are in agreement with those obtained by Farook and Khan (2010). Generally, the studied treatments can be arranged according to their effects on protein content and yield in the following descanding order: sulphuric acid $>$ elemental sulphur $>$ gypsum $>$ control.

Macronutrient contents

Data in Tables $5-8$ shows that N, P and $\mathrm{K}$ concentrations and uptake increased significantly due to addition of all treatments. Sulphuric acid treatment was superior for increasing the concentration and uptake of $\mathrm{N}, \mathrm{P}$ and $\mathrm{K}$ as compared to the other treatments.

Table 5 Macro (\%) and micronutrient $\left(\mathrm{mg} \mathrm{kg}^{-1}\right)$ contents in rice straw at maturity as affected by gypsum, elemental sulphur and sulphuric acid applications during the two growing seasons of 2011 and 2012 and their combined effect

\begin{tabular}{|c|c|c|c|c|c|c|c|}
\hline \multirow[t]{2}{*}{ Treatment } & \multirow[t]{2}{*}{ Season } & \multicolumn{2}{|c|}{ Macronutrient } & \multirow{2}{*}{$\begin{array}{r}\% \\
\mathbf{K}\end{array}$} & \multicolumn{3}{|c|}{$\begin{array}{l}\text { Micronutrient } \\
\left(\mathrm{mg} \mathrm{kg}^{-1}\right)\end{array}$} \\
\hline & & $\mathbf{N}$ & $\mathbf{P}$ & & $\mathrm{Fe}$ & Mn & Zn \\
\hline & 2011 & 1.25 & 0.16 & 1.45 & 51.7 & 47.9 & 21.0 \\
\hline \multirow[t]{2}{*}{ Control } & 2012 & 1.09 & 0.11 & 1.23 & 49.3 & 44.2 & 18.6 \\
\hline & $\begin{array}{c}\text { Combined } \\
2011\end{array}$ & $\begin{array}{c}1.17 \mathrm{c} \\
1.98\end{array}$ & $\begin{array}{c}\mathbf{0 . 1 4} \mathbf{b} \\
0.37\end{array}$ & $\begin{array}{c}1.34 b \\
2.14\end{array}$ & $\begin{array}{c}\mathbf{5 0 . 5} \mathrm{d} \\
68.3\end{array}$ & $\begin{array}{c}46.1 \mathrm{c} \\
62.1\end{array}$ & $\begin{array}{c}19.8 \mathbf{b} \\
30.5\end{array}$ \\
\hline \multirow[t]{2}{*}{ Gypsum } & 2012 & 1.93 & 0.34 & 2.23 & 65.9 & 59.4 & 33.6 \\
\hline & $\begin{array}{c}\text { Combined } \\
2011\end{array}$ & $\begin{array}{c}\mathbf{1 . 9 6} \mathbf{b} \\
1.92\end{array}$ & $\begin{array}{c}0.36 \mathrm{a} \\
0.43\end{array}$ & $\begin{array}{c}2.19 \mathrm{a} \\
2.28\end{array}$ & $\begin{array}{c}67.1 \mathrm{c} \\
70.1\end{array}$ & $\begin{array}{c}60.8 \mathrm{~b} \\
60.0\end{array}$ & $\begin{array}{c}32.0 \mathrm{a} \\
33.1\end{array}$ \\
\hline \multirow[t]{2}{*}{ Elemental Sulphur } & 2012 & 2.05 & 0.46 & 2.18 & 73.1 & 59.9 & 34.3 \\
\hline & $\begin{array}{c}\text { Combined } \\
2011\end{array}$ & $\begin{array}{c}1.98 \mathbf{b} \\
2.23\end{array}$ & $\begin{array}{c}\mathbf{0 . 4 5} \mathbf{a} \\
0.42\end{array}$ & $\begin{array}{c}2.23 a \\
2.21\end{array}$ & $\begin{array}{c}71.6 \text { b } \\
74.4\end{array}$ & $\begin{array}{c}59.9 \mathrm{ab} \\
62.7\end{array}$ & $\begin{array}{c}33.7 \mathbf{a} \\
35.7\end{array}$ \\
\hline \multirow[t]{2}{*}{ Sulphuric acid } & 2012 & 2.24 & 0.40 & 2.34 & 75.7 & 64.2 & 35.1 \\
\hline & Combined & $2.24 \mathrm{a}$ & $0.41 \mathrm{a}$ & $2.28 \mathrm{a}$ & $75.1 \mathrm{a}$ & $63.5 \mathrm{a}$ & $35.4 \mathrm{a}$ \\
\hline \multicolumn{2}{|c|}{ LSD $_{0.05}$ (Combined) } & 0.232 & 0.139 & 0.139 & 1.860 & 2.820 & 4.624 \\
\hline
\end{tabular}

See footnotes of Table 3 
This promoting effect could be related to the supplementary effect of gypsum and sulphur on reducing soil $\mathrm{pH}$, improving soil structure and increasing the availability of nutrients in soil. These results are in agreement with those obtained by Ali et al. (2008); Farook and Khan, (2010) and Jena and Kabi, (2012).

Table 6 Macro and micronutrient uptake by rice straw at maturity as affected by gypsum, elemental sulphur and sulphuric acid applications during the two growing seasons of 2011 and 2012 and their combined effect

\begin{tabular}{|c|c|c|c|c|c|c|c|}
\hline \multirow[t]{2}{*}{ Treatment } & \multirow[t]{2}{*}{ Season } & \multicolumn{3}{|c|}{$\begin{array}{l}\text { Macronutrient } \\
\left(\mathrm{kg} \mathrm{ha}^{-1}\right)\end{array}$} & \multicolumn{3}{|c|}{$\begin{array}{c}\text { Micronutrient } \\
\left(\mathrm{g} \mathrm{ha}^{-1}\right)\end{array}$} \\
\hline & & $\mathbf{N}$ & $\mathbf{P}$ & $\mathrm{K}$ & $\mathrm{Fe}$ & Mn & $\mathrm{Zn}$ \\
\hline \multirow{4}{*}{ Control } & 2011 & 115 & 14.7 & 133 & 476 & 440 & 193 \\
\hline & 2012 & 92.4 & 9.33 & 104 & 417 & 376 & 158 \\
\hline & Combined & $103 b$ & $12.4 \mathrm{~b}$ & $118 b$ & $445 \mathrm{c}$ & $407 \mathrm{~b}$ & $175 \mathrm{c}$ \\
\hline & 2011 & 205 & 38.3 & 221 & 705 & 643 & 314 \\
\hline \multirow[t]{3}{*}{ Gypsum } & 2012 & 203 & 35.7 & 235 & 695 & 626 & 352 \\
\hline & Combined & $204 a$ & $37.6 \mathrm{a}$ & 228 a & $700 \mathrm{~b}$ & $633 a$ & $333 \mathrm{~b}$ \\
\hline & 2011 & 204 & 45.7 & 243 & 745 & 638 & 352 \\
\hline \multirow[t]{3}{*}{ Elemental Sulphur } & 2012 & 221 & 49.5 & 235 & 788 & 645 & 369 \\
\hline & Combined & 212 a & $48.3 \mathrm{a}$ & $238 a$ & $767 a b$ & $643 a$ & $360 a b$ \\
\hline & 2011 & 248 & 46.7 & 245 & 826 & 695 & 395 \\
\hline \multirow[t]{2}{*}{ Sulphuric acid } & 2012 & 252 & 45.2 & 264 & 855 & 726 & 398 \\
\hline & Combined & $250 a$ & $46.0 \mathrm{a}$ & $255 a$ & $840 a$ & $712 a$ & 398 a \\
\hline LSD $_{0.05}$ (Combined) & & 20.53 & 4.973 & 35.99 & 54.43 & 51.24 & 23.82 \\
\hline
\end{tabular}

Table 7 Macro and micronutrients content in rice grains as at maturity as affected by gypsum, elemental sulphur and sulphuric acid applications during the two growing seasons of 2011 and 2012 and their combined effect

\begin{tabular}{|c|c|c|c|c|c|c|c|}
\hline \multirow[t]{2}{*}{ Treatment } & \multirow[t]{2}{*}{ Season } & \multicolumn{3}{|c|}{$\begin{array}{c}\text { Macronutrient } \\
(\%)\end{array}$} & \multicolumn{3}{|c|}{$\begin{array}{l}\text { Micronutrient } \\
\left(\mathrm{mg} \mathrm{kg}^{-1}\right)\end{array}$} \\
\hline & & $\mathbf{N}$ & $\mathbf{P}$ & $\mathbf{K}$ & $\mathrm{Fe}$ & Mn & Zn \\
\hline \multirow{3}{*}{ Control } & 2011 & 1.09 & 0.19 & 2.16 & 77.0 & 52.5 & 18.2 \\
\hline & 2012 & 0.89 & 0.23 & 2.35 & 79.9 & 59.8 & 13.6 \\
\hline & Combined & $0.99 \mathrm{c}$ & $0.21 b$ & $2.26 \mathrm{~b}$ & $78.4 \mathrm{~d}$ & $56.1 \mathrm{~d}$ & $15.9 \mathrm{c}$ \\
\hline \multirow{4}{*}{ Gypsum } & 2011 & 1.25 & 0.35 & 2.38 & 88.4 & 74.3 & 29.9 \\
\hline & 2012 & 1.30 & 0.38 & 2.42 & 91.5 & 77.6 & 31.2 \\
\hline & Combined & $1.28 \mathrm{~b}$ & $0.37 \mathrm{ab}$ & $2.40 \mathrm{ab}$ & $90.0 \mathrm{c}$ & $75.9 \mathrm{c}$ & $30.6 \mathrm{~b}$ \\
\hline & 2011 & 1.28 & 0.42 & 2.44 & 94.6 & 80.1 & 33.9 \\
\hline \multirow[t]{3}{*}{ Elemental Sulphur } & 2012 & 1.35 & 0.46 & 2.48 & 97.2 & 82.6 & 35.7 \\
\hline & Combined & $1.32 \mathrm{~b}$ & $0.44 a$ & $2.46 \mathrm{ab}$ & $95.9 \mathrm{~b}$ & $81.4 \mathrm{~b}$ & 34.8 a \\
\hline & 2011 & 1.38 & 0.48 & 2.51 & 98.6 & 85.0 & 35.5 \\
\hline \multirow[t]{2}{*}{ Sulphuric acid } & 2012 & 1.49 & 0.52 & 2.56 & 103 & 87.2 & 36.4 \\
\hline & Combined & $1.44 \mathrm{a}$ & $0.50 \mathrm{a}$ & $2.54 \mathrm{a}$ & $101 \mathrm{a}$ & 86.1 a & 35.9 a \\
\hline \multicolumn{2}{|c|}{ LSD $_{0.05}$ (Combined) } & 0.061 & 0.179 & 0.210 & 2.031 & 0.812 & 2.520 \\
\hline
\end{tabular}


Helmy, A. M. et al.

Table 8 Macro and micronutrients uptake by rice grains at maturity as affected by gypsum, elemental sulphur and sulphuric acid applications during the two growing seasons of 2011 and 2012 and their combined effect

\begin{tabular}{|c|c|c|c|c|c|c|c|}
\hline \multirow[t]{2}{*}{ Treatment } & \multirow[t]{2}{*}{ Season } & \multicolumn{3}{|c|}{$\begin{array}{c}\text { Macronutrient } \\
\left(\mathrm{kg} \mathrm{ha}^{-1}\right)\end{array}$} & \multicolumn{3}{|c|}{$\begin{array}{c}\text { Micronutrient } \\
\left(\mathrm{g} \mathrm{ha}^{-1}\right)\end{array}$} \\
\hline & & $\mathbf{N}$ & $\mathbf{P}$ & $\mathbf{K}$ & $\mathrm{Fe}$ & Mn & Zn \\
\hline & 2011 & 55.7 & 9.73 & 110 & 395 & 269 & 93.3 \\
\hline \multirow[t]{3}{*}{ Control } & 2012 & 50.0 & 12.9 & 132 & 450 & 336 & 76.4 \\
\hline & Combined & $53.3 \mathrm{~b}$ & $11.3 \mathrm{~b}$ & $122 b$ & $421 b$ & 302 b & $85.7 \mathrm{c}$ \\
\hline & 2011 & 112 & 31.4 & 213 & 790 & 664 & 267 \\
\hline \multirow[t]{2}{*}{ Gypsum } & 2012 & 120 & 35.0 & 224 & 845 & 717 & 288 \\
\hline & $\begin{array}{c}\text { Combined } \\
2011\end{array}$ & $\begin{array}{c}116 \mathbf{a} \\
117\end{array}$ & $\begin{array}{c}33.6 \mathbf{a} \\
38.6\end{array}$ & $\begin{array}{c}218 a \\
224\end{array}$ & $\begin{array}{c}819 a \\
867\end{array}$ & $\begin{array}{c}691 \mathbf{a} \\
736\end{array}$ & 279 b \\
\hline \multirow[t]{2}{*}{ Elemental sulphur } & 2012 & 127 & 43.1 & 233 & 912 & 774 & 336 \\
\hline & $\begin{array}{c}\text { Combined } \\
2011\end{array}$ & $\begin{array}{c}123 \mathbf{a} \\
129\end{array}$ & $\begin{array}{c}41.0 \mathbf{a} \\
44.8\end{array}$ & $\begin{array}{c}228 a \\
234\end{array}$ & $\begin{array}{c}890 \mathbf{a} \\
919\end{array}$ & $\begin{array}{c}755 \mathbf{a} \\
793\end{array}$ & $\begin{array}{c}324 a b \\
331\end{array}$ \\
\hline \multirow[t]{2}{*}{ Sulphuric acid } & 2012 & 141 & 49.0 & 243 & 974 & 824 & 345 \\
\hline & Combined & $135 a$ & $47.1 \mathrm{a}$ & 238 a & 948 a & $810 a$ & $338 a$ \\
\hline LSD $_{0.05}$ (Combined) & & 9.223 & 9.058 & 11.83 & 54.10 & 53.05 & 24.54 \\
\hline
\end{tabular}

A descending order characterized the effects of the applied amendments on macro and micronutrient contents as well as their uptake by both grains and straw can be represented by the following sequence: sulphuric acid > elemental sulphur > gypsum > control. Therefore, almost the highest $\mathrm{N}$ and $\mathrm{K}$-uptake by straw 250 and $255 \mathrm{~kg} \mathrm{ha}^{-1}$, respectively as well as $135,47.1$ and $238 \mathrm{~kg} \mathrm{ha}^{-1}$, respectively for grain were obtained due to the sulphuric acid treatment while for $P$ uptake by straw the highest $48.3 \mathrm{~kg} \mathrm{ha}^{-1}$ was achieved due to the elemental sulphur treatment.

\section{Micronutrients content}

As shown in Tables $5-8$. Fe, $\mathrm{Mn}$ and $\mathrm{Zn}$ concentrations and uptake values increased significantly due to addition of sulphuric acid, elemental sulphur and gypsum as compared to the control. Sulphuric acid treatment was of the most pronounced effect on both the concentrations and uptake values of $\mathrm{Fe}, \mathrm{Mn}$ and $\mathrm{Zn}$. The percent responses to $\mathrm{Fe}, \mathrm{Mn}$ and $\mathrm{Zn}$ uptake by rice straw over the control were $88.8,74.9$ and $127 \%$, respectively corresponding to 125,168 and $294 \%$, respectively for N,P and K uptake by grains . Jena and Kabi (2012) stated that sulphur application increased $\mathrm{Fe}, \mathrm{Mn}, \mathrm{Zn}$ and $\mathrm{Cu}$ uptake by rice from 580 to 880 , 766 to 986,175 to 270 and 56 to $87 \mathrm{~g} \mathrm{ha}^{-1}$,respectively.

\section{CONCLUSIONS}

Generally, significant improvement occurred due to the use of gypsum and sulphur on saline-sodic soils as sources of $\mathrm{Ca}$ and $\mathrm{S}$. The increases in rice yield and its contents and uptake of the macro and micronutrients is due to the (1) displacement of sodium by calcium, (2) decreasing soil $\mathrm{pH}$ and increasing the nutrient use efficiency of the crop Bello (2012). From the above mentioned results, it can be concluded that gypsum and sulphur application whether elemental sulphur or sulphuric acid had decreased the hazardous effect of salinity and sodicity of both 
soil and irrigation water and hence exerted favourable effects on growth and nutrient contents of rice. Sulphuric acid was the best among the used amendments for enhancing the productivity and rice quality.

\section{REFERENCES}

AACC (2000) Approved methods of the American association of cereal chemists, $10^{\text {th }}$ ed. AACC, publisher: American Association of Cereal Chemists, Hardcover USA, $1200 \mathrm{pp}$.

Abrol, I.P., Yadav, J.S.P. and Massoud, F.I. (1988) Salt -affected soils and their management. FAO Soils Bulletin 39. Food and Agriculture Organization of the United Nations, Rome.

Ali, Y. and Aslam, Z. (2005) Use of environmental friendly fertilizers in saline sodic soils. Int. J. Environ. Sci. Tech. 1(4): 97 - 98.

Ali, R., Khan, M. J. and Khattak, R. A. (2008) Response of rice to different sources of sulphur (S) at various levels and its residual effect on wheat in rice-wheat cropping system. Soil Environ., 27: $131-137$.

Amezketa, E., Aragues, R. and Gazol, R. (2005) Efficiency of sulfuric acid, mined gypsum and two gypsum by-products in soil crusting prevention and sodic soil reclamation. Agron. J., 97: $983-989$.

Badr, Z., Ali, A., Salim, M. and Niazi, B. H. (2002) Role of sulphur for potassium / sodium ratio in sunflower under saline conditions. Helia 25: 69- 78 .

Bates, L. S., Waldren, R. P. and Teare, I. D. (1973) Rapid determination of proline for water stress studies. Plant and soil 39: $305-307$.

Bello, W.B. (2012) Influence of gypsum application on wheat (Triticum aestivum) yield and components on saline and alkaline soils of Tigray region, Ethiopia. Greener J. of Agric. Sci., 2: 316 - 322 .

Black, C.A. (1965) Methods of soil analysis, I, II. Amer. Soc. Agron., Madison, Wisconsin, USA, $1572 \mathrm{pp}$.

Chapman, H.D. and Pratt, P.F. (1961) Methods of Analysis for Soils, Plants and Waters. Agric. Publ. Univ., of California, Riverside, 309 pp.

De Kok, L.J., Castro, A., Durenkamp, M.C., Stuiver, E.E., Westerman, S., Yang, L. and Stulen, I. (2002) Sulphur in plant physiology. The International Fertilizer Society, New York, Proceedings 500: 1-26.

Dobermann, A. and Fairhurst, T. (2000) Rice Nutrient disorder and nutrient management. Handbook Series. Potash and Phosphate Institute of Canada and International Rice Research Institute, $191 \mathrm{pp}$.

Duke, S.H. and Reisenaue, H.M. (1986) Roles and requirements of sulphur in plant nutrition. In: M. A. Tabatabai (ed.), Sulphur in Agriculture, Agronomy Series No. 27, American Society of Agronomy, Madison, Wisconsin, USA: 124 168.

Farook, A. and Khan, M.D. (2010) Response of mineral nutrient of rice to sulfidic material as sulphur fertilizer. Nat. and Sci. J. 8: $31-40$.

Ghaudhry, M.R. (2001) Gypsum efficiency in the amelioration of saline-sodic soils. International J. Agric. Biol. 3: 276 - 280. 
Helmy, A. M. et al.

Hassan, G., Sadiq, M., Jamil, M., Mehdi, S.M. and Sattar, A. (2001) Comparative performance of rice varities/lines in ameliorated and non ameliorated soils. International J. Agric. Biol. 3: $286-288$.

Hamza, M.A. and Anderson, W.K. (2003) Responses of soil properties and grain yields to deep ripping and gypsum application in a compacted loamy sand soil contrsted with a sandy clay loam soil in Western Australia. Australian J. Agric. Res., 54: 273 - 282.

Jena, D. and Kabi, S. (2012) Effect of gromor sulphur, bentonite sulphur pastilles on yield and nutrient uptake by hybrid rice - potato - green gram cropping system in an inceptisol. International Research J. of Agric. Sci. and Soil Sci., 2: $179-187$.

Jena, D., Sahoo, R., Sarangi, D.R. and Singh, M.V. (2006) Effect of different sources and levels of sulphur on yield and nutrient uptake by groundnut rice cropping system is an inceptisol of Orissa. J. Indian Soc. Soil Sci. 54: 126 129.

Leigh, R.A. (2001) Potassium homeostasis and membrane transport. J. of Plant Nutr. Soil Sci., 164: $193-198$.

Markus, D.K., Mckinnon, J.P. and Buccasuri, A.S. (1982) Automated Analysis of Nitrate and Ammonium Nitrogen in Soils. New Jersey, Agric. Exp. Sta. Publication N. D., 151: $17-84$.

Mazhar, A.M.A., Mahgoub, H.M. and Abd El-Aziz, G.N. (2011) Response of Schefflera arboricola L. to gypsum and sulphur application irrigated with different levels of saline water. Austr. J. Basic Appl. Sci., 5: 121 - 129.

Niazi, B.H., Ahmed, M., Hussain, N. and Salim, M. (2001) Comparison of sand, gypsum and sulphuric acid to reclaim a dense saline sodic soil. International J. Agric. \& Biology 3(3): $316-318$.

Peterburgski, A.V. (1968): Hand Book of Agronomic Chemistry. Kolos Publication House, Moscow. (In Russian) pp. 25 - 90.

Pratiksha, M.V., Neha, T.P., Indu, B.P. and Amar, N.P. (2010) Implications of calcium nutrition on the response of Butea monosperma (Fabaceae) to soil salinity. Annales de Biología, 32: $15-27$.

Russell, D.F. (1994): MSTAT-C v.2.1 (computer based data analysis software). Crop and Soil Sci. Department, Michigan State University, USA.

Sabir, G.K., Izhar, H.A., Muhammad, J.K. and Naveedullah (2007): Effect of various levels of gypsum application on the reclamation of salt affected soil grown under rice followed by wheat crop. Sarhad J. Agric., 23: 675 - 680 .

Saric, M.R.K., Cupina, T.and Geric, I. (1967) Chlorophyll determination. Univ. U. Noven Sadu Prakitikum is Kiziologize Bilijaka Beogard, Haucna, Anjiga.

Shaban, Kh.A., Nasef, M.A. and Tuntawy, M.F. (2009) Effect of cultivation periods with low quality water on saline soil properties and productivity. Egypt. J. Soil Sci., 49: $519-534$.

Soltanpour, N. (1985) Use of ammonium bicarbonate - DTPA soil test to evaluate elemental availability and toxicity. Soil Sci. Plant Anal., 16: $323-338$.

Tan, H., Rulin, X., Liuqiang, Z. and Jinping, L. (2000) Effect of various sulphur sources on yield and soil sulphur balance in a rice-rice cropping pattern in Guangxi province. Better Crops International, 14: $24-25$. 
Tandon, H.L.S. (1991) Sulphur Research and Agricultural Production in India. $3^{\text {rd }} \mathrm{Ed}$. The Sulphur Institute, Washington, D.C. USA. $140 \mathrm{p}$

USDA (1954) Diagnosis and improvement of saline and alkali soils. Agriculture Hand Book, 60, US Gov. Printing Office, Washington.

Wilson, C., Lesch, S. M. and Grieve, C.M. (2000) Growth stage modulates salinity tolerance of New Zealand Spinach (Tetragonia tetragonioides, Pall.) and Red Orach (Atriplex hortensis L.). Annals of Botany 85: 501 -509 .

Zhao, F. (1999) Sulphur assimilation and Effects on yield and quality of wheat. J. Cereal Sci., 30, $1-5$.

Zhao, F.J., Salmon, S.E., Withers, P.J.A., Monaghan, J.M., Evans, E.J., Shewry, P.R. and McGrath, S.P. (1999) Variation in the bread making quality and mineralogical properties of wheat in relation to sulphur nutrition under field conditions. J. of Cereal Sci., 30, 19-31.

تاثثير إضافة الجبس و الكبريت لتثيط تأثثر الأجهاد الناتج عن الملوحة وتحسين أنتاجية

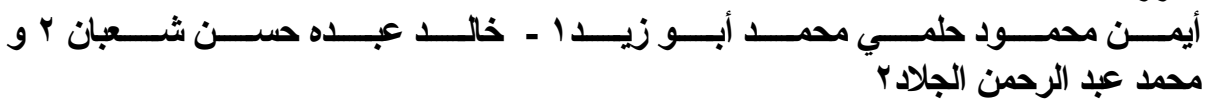

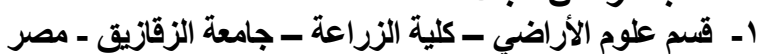

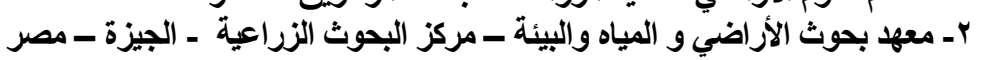

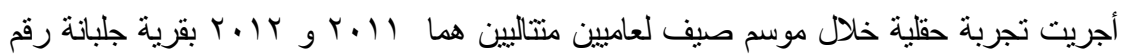

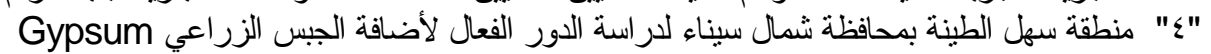

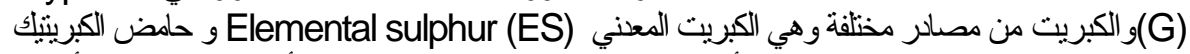

Sulphuric acid (SA) و وكنلك امتصاص بعض العناصر الغذائية الكبرى و الصغري الغرن (Oriza sativa L. var Sakha 101) ويمكن تلخيص أهم النتائج المتحصل عليها كما ياتئ:

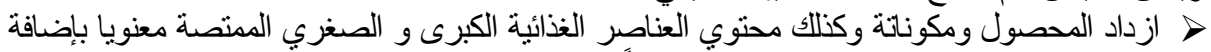

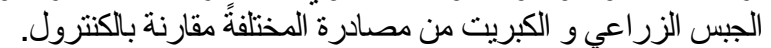

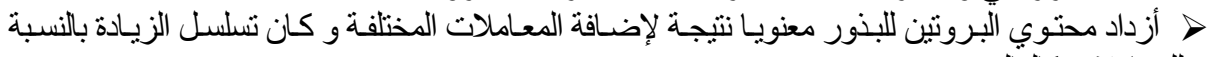

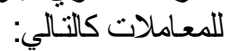

Sulphuric acid > Elemental sulphur > Gypsum > Control

الكبريتيك هي الأحسن علي الإطلاق مقارنـة بياقي المعاملات المستخدمة وذلك لجميع العناصر تحت الدراسة .

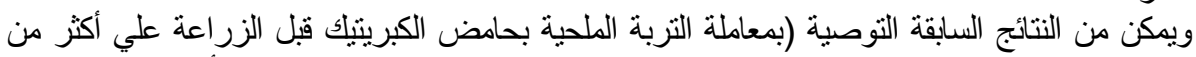

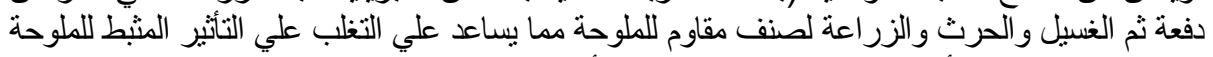
ورفع انتاجية وجودة الأرز الناتج في تلاك النو عية من الأراضي).

كلية الزراعة - جامعة المنصورة كلية الزراعة بمشتهر - جامعة بنها

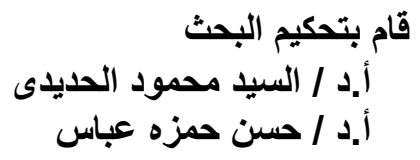

قام بتحكيم البحث

أ.د / حسن حمزه عباس معرد الحبد 